\title{
THE REASERCH OF THE DRY CHICKEN MANURE METHANOGENESIS STABLILITY IN SOLID-PHASE CONDITIONS
}

Ye. Shapovalov

National Center "Junior Academy of Sciences of Ukraine"

A. Salyuk, A. Kotynsky

National University of Food Technologies

\begin{tabular}{l}
\multicolumn{1}{c}{ Key words: } \\
Methanogenesis \\
Methane fermentation \\
Chicken manure \\
Adaptation \\
Biogas production \\
Dry fermentation \\
\hline \multicolumn{1}{c}{ Article history: } \\
Received 09.07.2018 \\
Received in revised form \\
26.07.2018 \\
Accepted 21.08.2018
\end{tabular}

Corresponding author:

Ye. Shapovalov

E-mail:

npnuht@ukr.net

\begin{abstract}
Luck of government standards for fertilizers formed in the methane fermentation process and seasonal functioning of the agricultural sector provide the problem of excess quantities of biofertelizer formation under methanogenesis, that limits its spread. Regulation of their production is possible by conducting dry fermentation or recycling of liquid phase. The paper is devoted to the study of the features of the methane fermentation of chicken manure at high concentrations of dry matter.

The studies were conducted in batch mode thirteen times at humidity of $78,80,82$ and $84 \%$. To assess the effectiveness of methanogenesis, production of biogas and methane, the concentration of dry matter, dry organic matter, ammonia, volatile fatty acids were measured. The biogas output varied from 294 to $331 \mathrm{~cm}^{3} / \mathrm{g}$ TS, and methane - from 181 to $208 \mathrm{~cm}^{3} / \mathrm{g}$ TS in mesophilic conditions. Production of biogas under thermophilic conditions was lower than under mesophilic ones, and it varied from 174.6 to $316 \mathrm{~cm}^{3} / \mathrm{g}$ TS and methane from 105.3 to 183.2 $\mathrm{cm}^{3} / \mathrm{g}$ TS. There was no correlation between methane content in biogas and humidity. The content of methane in the produced gas under mesophilic conditions ranged from 61.7 to $62.9 \%$, and under the thermophile conditions from 57.9 to $60.29 \%$. In general, the mesophilic mode was characterized by better performance. The statistical analysis proved a significant difference in the production of biogas, methane and the proportion of methane between the mesophilic and the thermophilic mode at a humidity of 78,80 , and $84 \%$. The coefficient of variation of methane production varied from $14.84 \%$ to $35.17 \%$ in mesophilic mode and from $14.4 \%$ to $78.21 \%$ in thermophilic mode. The moisture content had a much greater effect on the stability of the process in the thermophilic regime than in the mesophilic ones. The content of ammonium nitrogen at the end of fermentation was in the range of $599 \mathrm{mg} / \mathrm{l}$ to $4277 \mathrm{mg} / \mathrm{l}$. In general, the content of ammonia under thermophilic conditions (from 599 to $3214 \mathrm{mg} / \mathrm{l}$ ) was lower than under mesophilic ones (from 2171 to $4277 \mathrm{mg} / \mathrm{l}$ ).

The content of volatile fatty acids was in the range from 0.81 to $15.9 \mathrm{~g} / 1$ in the thermophilic mode and from 0.58 to $2.68 \mathrm{~g} / \mathrm{l}$ in mesophilic mode.
\end{abstract}

DOI: $10.24263 / 2225-2924-2018-24-4-7$ 


\section{ДОСЛІДЖЕННЯ СТАБІЛЬНОСТІ МЕТАНОГЕНЕЗУ КУРЯЧОГО ПОСЛІДУ У ТВЕРДОФАЗОВИХ УМОВАХ}

\section{Є.Б. Шаповалов}

Національний иентр «Мала академія наук Украӥни»

\section{А.І. Салюк, А.В. Котинський}

Національний університет харчових технологій

В умовах відсутності державних стандартів щодо добрив, утворених у процесі метанової ферментаиії, та сезонності функціонування аграрного сектору виникає проблема утворення надмірної кількості стоків після метаногенезу, щио обмежує його поширення. Регулювання кількості утворення стоків можливе шляхом проведення твердофазової ферментачії або рециркуляиії рідкої фази. Стаття присвячена дослідженню особливостей процесу метанової ферментації курячого посліду за високих конщентрацій сухих речовин.

Дослідження проводили в періодичному режимі у тринадиятикратній повторності при вологостях 78, 80, 82 та 84\%. Для оцінки ефективності метаногенезу вимірювали виробництво біогазу та метану, конщентрациію сухих речовин, сухих органічних речовин, амонійного Нітрогену, летких жирних кислот. Вихід біогазу варіювався від 294 до $331 \mathrm{~cm}^{3} / 2$ СОР, а метану від 181 до $208 \mathrm{~cm}^{3} / 2$ СОР у мезофільних умовах. Виробництво біогазу у термофільних умовах було меншим, ніж у мезофільних, та варіювалось від 174,6 до $316 \mathrm{~cm}^{3} / 2$ COP, а метану - від 105,3 до 183,2 $\mathrm{cm}^{3} / 2$ СОР. Залежності між вмістом метану у біогазі та вологістю не спостерігалось. Вміст метану у виробленому газі у мезофільних умовах варіювався від 61,7 до 62,9\%, а у термофільному - від 57,9 до 60,29\%. Загалом мезофільний режим характеризувався кращими показниками. Статистичний аналіз вказував на значиму різницю за виробництвом біогазу, метану та часткою метану між мезофільним і термофільним режимом при вологості 78, 80 та 84\%. Коефіціснт варіації виробництва метану варіювався від 14,84\% до 35,17\% у мезофільному режимі та від 14,4\% до 78,21\% у термофільному режимі. Вміст вологи мав значно більший вплив на стабільність процесу у термофільному режимі, ніж у мезофільному режимі. Вміст амонійного Нітрогену наприкінщі ферментації був в межах від 599 мг/л до 4277 мг/л. В загальному, вміст амонійного Нітрогену у термофільних умовах (від 599 до 3214 мг/л) був нижчим, ніж у мезофільних (від 2171 до 4277 мг/л).

Вміст ЛЖК знаходився в межах від 0,81 до 15,9 г/л у термофільному режимі та від 0,58 до 2,68 г/л у мезофільному режимі.

Ключові слова: метаногенез, метанова ферментація, курячий послід, адаптаиія, біогаз, твердофазова ферментаиія.

Постановка проблеми. Відповідно до європейських тенденцій при поводженні з відходами [7], вони першочергово повинні утилізуватись 3 виробництвом енергії. Такий підхід може бути забезпечений шляхом метанової 
ферментації. Окрім того, стоки 3 біогазової установки $\epsilon$ високоякісним органо-мінеральним добривом. 3 іншої боку, в умовах відсутності державних стандартів щодо цього виду добрив і сезонності функціонування аграрного сектору, виникає проблема утворення надмірної кількості стоків [2; 13]. Регулювання їх кількості можливе шляхом проведення твердофазової ферментації або рециркуляції рідкої фази. Однак при застосуванні даних методів для відходів птахівництва можуть виникнути проблеми 3 накопиченням інгібіторів, головним чином амонійного Нітрогену. Попередні дослідження твердофазової ферментації, що проводились на органічній складовій твердих побутових відходів, вказували на існування ряду переваг твердофазової ферментації, зокрема зменшення розмірів біогазової установки, зниження вартості експлуатаційних витрат та вищий об'ємний вихід метану $[10 ; 16]$. Твердофазова ферментація курячого посліду є недостатньо дослідженою та актуальною.

Аналіз останніх досліджень і публікацій. Метанову ферментацію за вмістом вологи поділяють на твердофазова та рідкофазова. Це пов'язано 3 тим, що при певному вмісті вологи субстрат втрачає текучість. Загальноприйнятої межі розподілу на твердофазова та рідкофазова ферментацію не існує. Однак багато авторів визначають цю межу рівною 85\% [7; 11$]$.

Результати наших попередніх досліджень вказували на можливість проведення твердофазової ферментації курячого посліду, однак вона характеризувалась значно нижчими показниками продуктивності, ніж рідкофазова. Деякі повторності твердофазової ферментації характеризувались значно вищим виходом біогазу та метану від середнього значення, що може свідчити про можливість метаногенного консорціуму до адаптації $[1 ; 15 ; 16]$.

Інші автори, що проводили експериментальні дослідження в умовах твердофазової ферментації, отримали різні результати виробництва біогазу та метану (табл. 1). Це, ймовірно, також пов'язано 3 можливістю метаногенного консорціуму до адаптації.

Таблиия 1. Результати попередніх досліджень твердофазової ферментації

\begin{tabular}{|c|c|c|c|c|c|c|}
\hline Автор & $\begin{array}{c}\text { Вологість, } \\
\%\end{array}$ & $\begin{array}{c}\text { Температура, } \\
{ }^{\circ} \mathrm{C}\end{array}$ & $\begin{array}{c}\text { Виробництво } \\
\text { метану, см } / \Gamma \\
\text { СОР }\end{array}$ & $\begin{array}{c}\text { Вміст } \\
\text { амонію, } \\
\text { Г/л }\end{array}$ & $\begin{array}{c}\text { Вміст } \\
\text { ЛЖК, } \\
\text { Г/л }\end{array}$ & $\begin{array}{c}\text { Період дослідже- } \\
\text { ння/гідравлічний } \\
\text { час утримання }\end{array}$ \\
\hline 1 & 2 & 3 & 4 & 5 & 6 & 7 \\
\hline $\begin{array}{c}\text { Салюк [1; } \\
15 ; 16]\end{array}$ & 84 & 35 & 72 & 4,96 & 0,39 & 50 \\
\hline Салюк [1] & 84 & 50 & 113 & 2,12 & 2,37 & 50 \\
\hline Сінкора [17] & 77 & 38 & 247 & $1,35-2$ & - & 32 \\
\hline $\begin{array}{c}\text { Раджагопал } \\
{[14]}\end{array}$ & 70 & 20 & 162 & - & - & $\begin{array}{c}\text { Безперервний, 26 } \\
\text { діб }\end{array}$ \\
\hline \begin{tabular}{c} 
Абулянін [3] \\
\hline Абулянін [8]
\end{tabular} & 77.5 & 37 & 5 & 7 & - & $\begin{array}{c}\text { До припинення } \\
\text { виробництва, } \\
\text { близько 38 діб }\end{array}$ \\
\hline Абулянін [8] & 80 & 35 & 139,6 & 2,1 & 6,1 & 40 \\
\hline Абулянін [4] & 75 & 35 & 8,2 & 16 & 72 & 8 \\
\hline Абулянін [4] & 75 & 45 & 8,2 & 16 & 72 & 8 \\
\hline
\end{tabular}




\begin{tabular}{|c|c|c|c|c|c|c|}
\hline \multicolumn{9}{|c|}{} & \multicolumn{5}{c}{ Продовження табл. 1 } \\
\hline 1 & 2 & 3 & 4 & 5 & 6 & 7 \\
\hline Абулянін [4] & 75 & 55,65 & 0 & 16 & 48 & 8 \\
\hline Маркау [12] & 85 & 35 & 117 & 8 & 6,5 & $\begin{array}{c}\text { Напівбезперевний, } \\
30 \text { діб час } \\
\text { обороту, 2 } \\
\text { обороти }\end{array}$ \\
\hline Маркау [12] & 80 & 35 & 51 & 10 & 16 & $\begin{array}{c}\text { Напівбезперевний, } \\
\text { обоб час } \\
\text { обороту, 2 } \\
\text { обороти }\end{array}$ \\
\hline Фероу [8] & 80 & 35 & 140 & 10,2 & - & 65 \\
\hline Фероу [5; 8] & 80 & 35 & 470 & 2,46 & - & 35 \\
\hline
\end{tabular}

*виробництво біогазу

Метою дослідження $є$ виявлення особливостей метаногенезу курячого посліду за умов твердофазової ферментації.

Матеріали і методи. Дослідження проводили у пластикових реакторах загальним об'ємом 50 мл у тринадцятикратній повторності. У реакторі розміщали 20 г субстрату з часткою активного мулу 10\%. Вологість субстрату становила $78 \%, 80 \%, 82 \%$ та 84\%. Для розбавлення до необхідної вологості використовували водопровідну воду. Реактори розміщувались у сухоповітряному термостаті (ТС 80 M2, Росія), що підтримував температуру $35^{\circ} \mathrm{C}$ для реакторів, що працювали у мезофільному режимі, та $50^{\circ} \mathrm{C}$ - для реакторів, що працювали у термофільному режимі. Експеримент проводили у періодичному режимі протягом 160 діб.

Вихід біогазу визначали щоденно, а вміст метану визначали в міру накопичення необхідної кількості біогазу для аналізу. Концентрацію СР, сухих органічних речовин (COP), амонійного Нітрогену, вільного аміаку, летких жирних кислот, вільних летких жирних кислот субстрату різної вологості визначали на початку і в кінці кожного експерименту. Для статистичної обробки результатів застосовували t-test i тест Манна-Уітні.

Результати і обговорення. У мезофільних умовах виробництво біогазу 3 одиниці маси було практично однаковим за всіх вологостей. Вихід біогазу варіювався від 294 до $331 \mathrm{~cm}^{3} /$ Г СОР, а метану — від 181 до $208 \mathrm{~cm}^{3} / \Gamma$ СОР. У мезофільному режимі максимальний вихід біогазу з одиниці маси спостерігався при вологості субстрату 84\%. Виробництво метану з одиниці маси у мезофільних умовах показано на рис. 1.

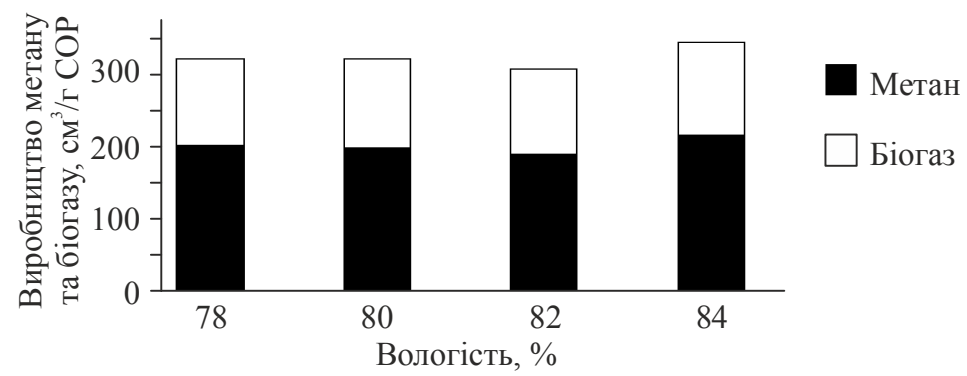

Рис. 1. Виробництво метану з одиниці маси у мезофільних умовах 
Виробництво біогазу у нашому попередньому дослідженні при твердофазовій ферментації варіювалось від 66,2 до $175 \mathrm{~cm}^{3} / \Gamma \mathrm{COP}$, а метану - від 11,9 до $72 \mathrm{~cm}^{3} / \Gamma$ СОР у мезофільних умовах. Максимальний вихід біогазу та метану 3 одиниці маси був при вологості 84\%, що відповідає результатам даного дослідження. Тож виробництво біогазу та метану характеризувалось вищими показниками, ніж у попередньому дослідженні [1].

Інші автори, що проводили дослідження метаногенезу курячого посліду в умовах твердофазової ферментації у мезофільному режимі отримали виробництво метану від 5 до $247 \mathrm{~cm}^{3} / \Gamma$ СОР. Найбільший вихід метану спостерігався у дослідженні Камерона Сінкори і співавт. при $38^{\circ} \mathrm{C}$, що є вищим, ніж результати дослідження [16].

Виробництво біогазу в термофільних умовах варіювалось від 174,6 до $316 \mathrm{~cm}^{3} /$ Г СОР, а метану — від 105,3 до $183,2 \mathrm{~cm}^{3} / \Gamma$ СОР. У термофільному режимі максимальний вихід біогазу з одиниці маси був при вологості субстрату $82 \%$. Імовірно, у зв'язку з нестабільністю процесу у цьому дослідженні, спостерігалась тенденція до зростання виробництва біогазу при зростанні вологості лише в діапазоні вологостей $78-82 \%$ (рис. 3 ).

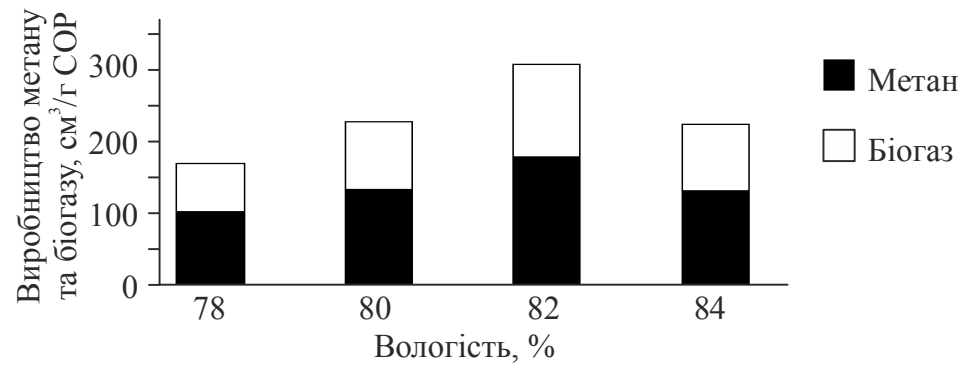

Рис. 2. Виробництво метану з одиниці маси у термофільних умовах

У термофільному режимі у попередніх дослідженнях виробництво біогазу варіювалось від 10 до 230,3 cм³/Г СОР, а метану - від 1 до $113 \mathrm{~cm}^{3} /$ Г СОР. Максимальний вихід метану та біогазу був характерний для вологості 84\%.

Виробництво метану в термофільному режимі було вищим, ніж у попередніх дослідженнях, що пов'язано з більшим періодом проведення процесу. Найвищі показники виробництва метану були отримані Абуляніном та співавт. Так, у їхньому дослідженні виробництво метану при вмісті сухих речовин $20 \%$ при $55^{\circ} \mathrm{C}$ становило $139,6 \mathrm{~cm}^{3} / \Gamma$ СОР [7].

Ефективність метаногенезу у цьому дослідженні зростала зі збільшенням вмісту вологи, а вплив вологості на метаногенез у термофільному режимі значно більший, що відповідало результатам попереднього дослідження.

Статистичні результати вказують на значиму різницю за виробництвом біогазу та метану між мезофільним і термофільним режимом при вологості 78 (показник Мана-Уітні, $P=0,003$ та показник Мана-Уітні, $P=<0,001$, відповідно), 80 (показник Мана-Уітні, $P=0,002$ та t-тест, $P=0,002$, відповідно) та $84 \%$ (показник Мана-Уітні, $P=0,001$ та показник Мана-Уітні, $P=$ $=<0,001$ відповідно). Виробництво біогазу та метану при вологості $82 \%$ не характеризувалось значимою різницею між мезофільних та термофільних 
умовах (показник Мана-Уітні, $P=1,000$ та показник Мана-Уітні, $P=0,259$ відповідно).

Залежності між вмістом метану у біогазі та вологістю не спостерігалось. Вміст метану у виробленому газі у мезофільних умовах варіювався від 61,7 до $62,9 \%$, а у термофільному - від 57,9 до $60,29 \%$. Відношення виробленого метану до біогазу при вологості $78-84 \%$ субстрату в мезофільному і термофільному режимі представлено на рис. 3.

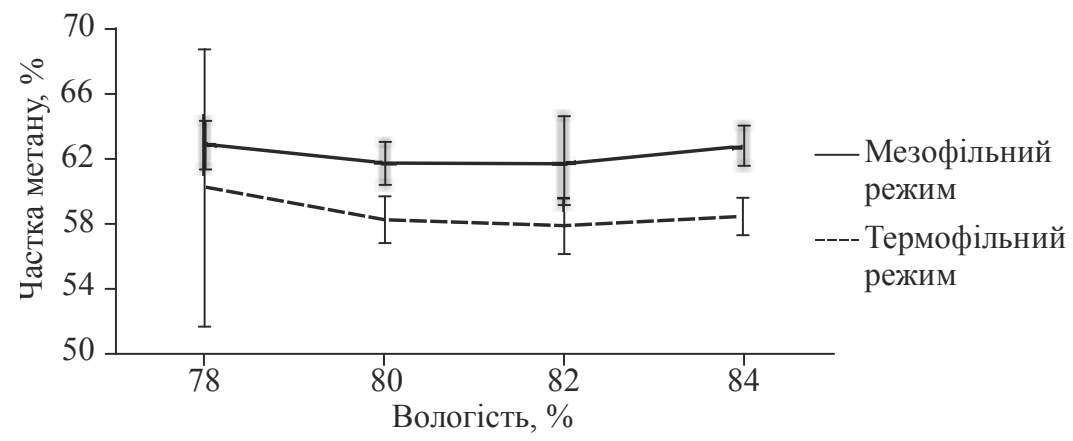

Рис. 3. Відношення виробленого метану до біогазу при вологості субстрату $78-84 \%$ в мезофільному і термофільному режимі

Статистичні результати вказують на значиму різницю між мезофільним i термофільним режимом за часткою метану при вологості 78 (показник МанаУітні, $P=<0,001), 80(t$-тест, $P=<0,001)$ та $84 \%(t$-тест, $P=0,008)$. Частка метану при вологості $82 \%$ не характеризувалась значимою різницею між мезофільними і термофільними умовами $(t$-тест, $P=0,077)$.

Для порівняння стабільності процесу було проведено статистичну обробку результатів та використано коефіцієнт варіації виробництва метану для оцінки стабільності процесу. Коефіцієнт варіації виробництва метану варіювався від $14,84 \%$ до $35,17 \%$ у мезофільному режимі та від $14,4 \%$ до $78,21 \%$ у термофільному режимі. Доцільно зазначити, що вміст вологи мав значно більший вплив на стабільність процесу у термофільному режимі, ніж у мезофільному режимі. Коефіцієнт варіації виробництва метану у мезофільному та термофільному режимі представлено на рис. 4.

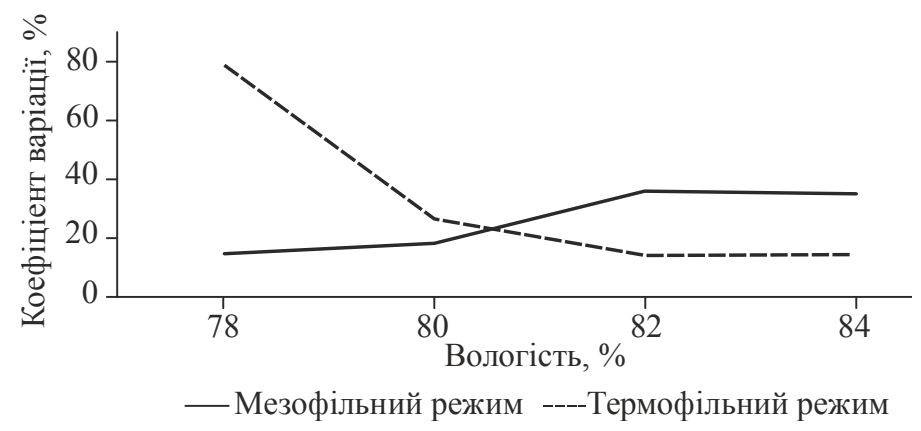

Рис. 4. Коефіціснт варіації виробництва метану в мезофільному і термофільному режимі 
Отже, процес був нестабільним як у термофільних, так і у мезофільних умовах. Окрім того, для виробництва метану та біогазу нормальний розподіл значень не був характерним, що також свідчить про низьку стабільність процесу. Тож твердофазову ферментацію курячого посліду недоцільно застосовувати для зниження водоспоживання при утилізації відходів птахівництва

Зміни у субстраті. Вміст амонійного Нітрогену наприкінці ферментації був в межах від 599 мг/л до 4277 мг/л. Загалом, вміст амонійного Нітрогену в термофільних умовах (від 599 до 3214 мг/л) був нижчим, ніж у мезофільних (від 2171 до 4277 мг/л).

Вміст ЛЖК знаходився в межах від 0,81 до 15,9 г/л у термофільному режимі та від 0,58 до 2,68 г/л у мезофільному режимі. Тобто вміст ЛЖК був вищим у термофільних умовах. Залежності між вмістом ЛЖК та ефективністю метаногенезу не виявлено.

\section{Висновки}

1. Вперше детально досліджено твердофазову ферментацію курячого посліду.

2. Максимальний вихід біогазу та метану спостерігався у мезофільному режимі при вологості субстрату $84 \%$ і становив $331 \mathrm{~cm}^{3} / \Gamma$ СОР та $208 \mathrm{~cm}^{3} / \Gamma$ СОР, відповідно, за повний період дослідження.

3. Процес $є$ досить нестабільним як у термофільних, так і мезофільних умовах. У термофільному режимі процес $є$ більш нестабільним, а його стабільність різко знижувалась зі зменшенням вологості. У мезофільному такої тенденції не простежувалось.

4. Підтверджено, що ефективність процесу зростала зі зростанням вмісту вологи; термофільний режим характеризувався більшою залежністю від вмісту вологи.

5. Твердофазову ферментацію курячого посліду недоцільно застосовувати для зниження водоспоживання при утилізації відходів птахівництва

\section{Література}

1. Влияние водопотребления на эффективность метанового брожения куриного помета / А.И. Салюк, С.А. Жадан, Е.Б. Шаповалов, Р.А. Тарасенко // International Scientific Journal for Alternative Energy and Ecology (ISJAEE). — 2015. — № 15-16. - C. 53-58.

2. Якушко С.И. Выбор технологических режимов в установках для производства биогаза / С.И. Якушко // Вісник СумДУ. — 2006. — № 5(89). — С. 102-108.

3. Abouelenien F. Dry mesophilic fermentation of chicken manure for production of methane by repeated batch culture / F. Abouelenien, Y. Nakashimada, N. Nishio // Journal of Bioscience and Bioengineering. - 2009. - № 3. - C. 293-295.

4. Abouelenien $F$. Dry anaerobic ammonia-methane production from chicken manure / Fatma Abouelenien // Appl Microbiol Biotechnol. — 2009. — № 82. - C. 757-764.

5. Anaerobic Digestion of Poultry Manure: Process Optimization Employing Struvite Precipitation and Novel Digestion Technologies / C. Farrow, A. Crolla, C. Kinsley, E. McBean. // Environmental Progress \& Sustainable Energy. - 2016. - C. 1-10.

6. Different aspects of dry anaerobic digestion for bio-energy: An overview / [R. Kothari, A. K. Pandey, S. Kumar та ін.]. // Renewable and Sustainable Energy Reviews. - 2014. № 39. - C. $175-192$. 
7. Directive 2008/98/EC [Електронний ресурс] // eur-lex. — 2008 [Електронний ресурс]. Режим доступу : http://eur-lex.europa.eu/legal-content/En/TXT/?uri=celex:32008L0098.

8. Dry Co-Digestion of Poultry Manure with Agriculture Wastes / F.Abouelenien, Y. Namba, N. Nishio, Y. Nakashimada // Appl Biochem Biotechnol. — 2015. — № 2015.

9. Farrow C. Anaerobic Digestion of Poultry Manure : дис. канд. / Farrow Cameron Guelph, Ontario, Canada, 2016. - 144 c.

10. Karaalp D., Caliskan G., Azbar N. Performance evaluation of a biogas reactor processing chicken manure with high solids content: digital proceeding of the ICOEST Cappadocia 2013. Nevsehir, Turkey, June 18-21, 2013. - P. 768-773.

11. Li Y. Solid-state anaerobic digestion for methane production from organic waste / Y. Li, S. Park, J. Zhu. // Renewable and Sustainable Energy Reviews. — 2011. — № 15. — C. 821 - 826.

12. Markou G. Improved anaerobic digestion performance and biogas production from poultry litter after lowering its nitrogen content/Giorgos Markou. // Environmental Progress \& Sustainable Energy. - 2015.

13. Mono-fermentation of chicken manure: Ammonia inhibition and recirculation of the digestate / H. Nie, H. Jacobi, K. Strach [et. al.] // Bioresource Technology. — 2015. — № 178. P. 238-246.

14. Rajagopal, R.,Start-up of dry anaerobic digestion system for processing solid poultry litter using adapted liquid inoculum, Process Safety and Environment Protection (2016), http://dx.doi.org/10.1016/j.psep.2016.05.003.

15. Salyuk A. Thermophilic methane digestion of chicken manure/ A. Salyuk, S. Zhadan, E. Shapovalov // Ukrainian Food Journal. — 2014. — Vol. 3(4). — P. 587-594.

16. Salyuk A. Thermophilic methane fermentation of chicken manure in a wide range of substrate moisture contents / A. Salyuk, S. Zhadan, E. Shapovalov. // Journal of Food and Packaging Science, Technique and Technologies. - 2015. - Vol. 4(7). - P. 36-40.

17. Sinkora $M$. Monitoring of dry anaerobic fermentation in experimental facility with use of biofilm reactor / M. Šinkora, M. Havlíček. // Acta Universitatis Agriculturae et Silviculturae Mendelianae Brunensis. — 2011. — № 6. - C. 343-354. 